\title{
R18 - DESENVOLVIMENTO DE TESTE PARA DIAGNÓSTICO MOLECULAR DE BACILOS GRAM-NEGATIVOS PRODUTORES DAS CARBAPENEMASES MAIS PREVALENTES NO BRASIL
}

Daniele Rocha ${ }^{1}$, Elisabete de Andrade $^{1}$, Marcela Fontana ${ }^{1}$, Marise Asensi ${ }^{2}$ e Thiago Chagas $^{2}$ Antonio G. P. Ferreira ${ }^{1}$, Patricia Alvarez ${ }^{1}$

\section{Bio-Manguinhos/FIOCRUZ \\ 2 IOC/FIOCRUZ}

Objetivo: A incidência de SEPSE tem aumentado ao longo das últimas décadas e, juntamente com suas sequelas, é a principal causa de morbimortalidade em UTIs gerais. No Brasil, estima-se que ocorram, pelo menos, 200 casos de sepse/ano, com mortalidade de $50 \%$. O objetivo do presente trabalho é desenvolver um kit de diagnóstico molecular laboratorial, com base na plataforma tecnológica de PCR em tempo real, para detecção dos genes das principais carbapenemases existentes no Brasil (KPC, NDM, OXA-48, SPM-1, OXA-23, OXA-51).

Metodologia: O ensaio de PCR em tempo real foi padronizado com bactérias sonicadas, consideradas controle positivo (estabelecida na PCR convencional), e bactérias submetidas à lise térmica. Para lise térmica bacteriana foram utilizadas duas condições: a) previamente aquecidas $95^{\circ} \mathrm{C} / 5^{\prime}$ e b) colocadas diretamente na reação de PCR, obtendose a lise durante a ativação enzimática, (TAQ hot start) $95^{\circ} \mathrm{C} / 10^{\prime}$. O controle interno utilizado foi o gene constitutivo 16SrRNA. Foram testadas duas ciclagens de PCR: Protocolo Bio-Manguinhos e Protocolo CDC. Para os experimentos foram utilizadas cepas KPC+, NDM+ e KPC-/NDM-, e realizados ensaios de PCR em Tempo Real realizados em "single" e em multiplex.

Resultados: Para os ensaios em "single" observou-se amplificação satisfatória para $\mathrm{KPC}+, \mathrm{NDM}+\mathrm{e}$ 16SrRNA independente da lise térmica (prévia ou não) e/ou sonicação. O PCR multiplex obteve resultados muito satisfatórios, quando comparados com os resultados em "single" de cada cepa e em comparação com as amostras sonicadas. Não houve diferença de amplificação entre as duas ciclagens testadas. 
Conclusão: Das condições avaliadas todas obtiveram êxito, sendo a coleta direta da placa de petri e a ciclagem adaptada do CDC, o modo mais simples e rápido para realização do teste. Pode-se concluir que a prova de conceito foi alcançada, por intermédio dos resultados preliminares obtidos que são altamente satisfatórios, podendo futuramente ser incorporado na rotina de testes para identificação e detecção de cepas bacterianas isoladas de pacientes com quadro clínico de SEPSE. 